\title{
Paisagem com mulher e mar ao fundo: como esquecer os fluxos e refluxos das ondas?
}

Ângela Beatriz de Carvalho Faria (1)

\section{RESUMO}

Partindo do princípio de que "a história e a arte ensinam que a revolta costuma nascer do luto e se propaga num turbilhão que mistura lamentos pessoais e coletivos, o próximo e o distante, numa extraordinária emoção coletiva" (DIDI-HUBERMAN, 2019, p. 115), Georges DidiHuberman, filósofo e historiador da arte, no artigo "Ondas, torrentes e barricadas", publicado na Revista Serrote do Instituto Moreira Salles, mostra-nos como as sublevações ou insurreições políticas ("potências" ou "ondas"), de modo gradativo e imperceptível, tornam-se capazes de fazer erodir um poder constituído que se julgava inamovivel ("barragem" ou "falésia"). E exatamente isso que iremos encontrar em Paisagem com mulher e mar ao fundo, romance de Teolinda Gersão, uma das mais consagradas escritoras portuguesas contemporâneas, reeditado em 2019: a presença de uma revolta popular, em uma aldeia à beira-mar plantada, sitiada por Instituições e imagens-ícone do fascismo, na época do governo

Recebido em: $16 / 12 / 2020$ Aceito em: 16/01/2021

a Universidade Federal do Rio de Janeiro, Faculdade de Letras, Programa de Pós-Graduação em Letras Vernáculas, Rio de Janeiro, RJ, Brasil. E-mail: decarvalhofariaangelabeatriz@gmail.com

\section{Como citar:}

FARIA, A.B.C. Paisagem com mulher e mar ao fundo: como esquecer os fluxos e refluxos das ondas? 
de António de Oliveira Salazar. O romance em questão, ao tematizar, metaforicamente, a Revolução de Abril de 1974, problematiza os conceitos de distopia e utopia, põe em cena "o circuito dos afetos, os corpos políticos e o desamparo", o que, na ótica de Vladimir Safatle (2019, título), promove "o fim do individuo", circunscrevendo-o como um agente de transformação social.

Palavras-chave: Paisagem com mulher e mar ao fundo, Teolinda Gersão, Utopia, Distopia.

A história e a arte ensinam que a revolta costuma nascer do luto e se propaga num turbilhão que mistura lamentos pessoais e coletivos, o próximo e o distante, numa extraordinária emoção coletiva.

Georges Didi-Huberman. "Ondas, torrentes e barricadas"

Portugal. O ultramar. Um retrato de Salazar e do país durante a ditadura. Uma mulher, mãe, que perde um filho na guerra colonial, a mais injusta e absurda de todas as guerras. A sua voz é a de todos os que, durante mais de quatro décadas, foram silenciadas pelo poder do opressor.

Publicado originalmente em 1982, este é um romance que importa revisitar para lembrar ao leitor que houve um tempo em que o mar era paisagem árida e Portugal um país que calava e obedecia.

Contracapa de Paisagem com mulher e mar ao fundo

Desafiada pela competente intelectual e querida amiga, Professora doutora Ângela Dias, a submeter um artigo à Revista Gragoatá e a desvendar a dialética inerente ao conceito de distopia, que oscila entre "resistência" e "submissão", ocorreume reler o ensaio "Utopia, revolução, distopia e democracia”, de Marilena Chauí (2019), inserido em Mutações: a outra margem da política (Org. Adauto Novaes, Companhia das Letras), assim como o artigo "Ondas, torrentes e barricadas" de autoria do filósofo e historiador da Arte, Georges Didi-Huberman (2019), publicado na Revista "Serrote" do Instituto Moreira Salles, a 
${ }^{1}$ Consideramos

Paisagem com mulher e mar ao fundo uma "poética narrativa", uma vez que apresenta simultaneamente, características do gênero narrativo e do lírico. O relato de um levante político, sem perder a intenção de uma denúncia social, reveste-se de uma dimensão lírica ao privilegiar a subjetividade das personagens, assinalada por um "levante de emoções." Didi-Huberman, ao comentar sobre as imagens surpreendentes das barricadas nas obras de Gustave Coubert, Charles Baudelaire

Arthur Rimbaud, pronuncia-se da seguinte forma: “É como se houvesse, nessa época, um movimento de atração recíproco e contínuo entre lirismo e política, impulsos poéticos e práticas de levante." (DIDI-HUBERMAN, 2019, p. 137). fim de reinterpretar, a partir de um novo olhar, um romance que me é extremamente caro - Paisagem com mulher e mar ao fundo, de Teolinda Gersão, uma das mais consagradas escritoras portuguesas contemporâneas.

Reeditada em Portugal, em 2019, tal poética narrativa ${ }^{1}$, inserida na contemporaneidade do século XXI, põe em cena o processo de mutação da política salazarista, assinalada pela opressão, desigualdade, falta de liberdade, sofrimento e autoritarismo. O contexto sombrio e distópico, inerente a quarenta e oito anos de uma ditadura aparentemente inamovível, somente chegará ao fim com a Revolução dos Cravos, em 25 de abril de 1974 - "dia inteiro inicial e limpo" que permitirá aos cidadãos portugueses, imersos na "noite e no silêncio", o habitar de forma livre "a substância do tempo", como tão bem assinalou Sophia de Melo Breyner Andresen (1977) em um dos seus poemas intitulado " 25 de Abril". Na produção ficcional referida, o imaginário imperial e ultramarino, subitamente dilacerado e morto, refletirá a passagem da distopia para a utopia, através de um ato de revolta - a destituição do "Senhor do Mar", imagem-ícone do totalitarismo análoga à "O.S." (Oliveira Salazar, nome próprio não pronunciado, apenas sugerido no espaço ficcional).Essa imagem religiosa e representante da opressão, cristalizada no cenário político de uma aldeia interiorana à beira-mar plantada, será derrubada de seu andor do alto da falésia por uma revolta popular, o que possibilitará ao leitor a decifração da alegoria contida no texto - a queda do regime de António de Oliveira Salazar - e as ações inerentes a ela: a libertação do país do jugo opressor, o fim da guerra colonial e a abolição das "províncias" ou colônias ultramarinas portuguesas formadoras do Império que se julgava inabalável. No romance em questão, barcos que partiram do cais da agonia e do desastre, levando os combatentes portugueses para a África, retornam à pátria e finda-se "o tempo em que o mar era paisagem árida e Portugal um país que calava e obedecia" (GERSÃO, 2019, contracapa), como atestam as palavras presentes na Contracapa da última edição de Paisagem com mulher e mar ao fundo.

Cumpre observar que ambas as epígrafes selecionadas estabelecem um diálogo entre si e revelam a postura ética, estética e política de Georges Didi-Huberman e Teolinda Gersão - autores que nos ensinam "a ler o invisível, o mudo, 
o inaudito. Ou até mesmo a ler o que ainda não foi escrito, e que faz pulsar o sintoma dos interstícios, das cesuras, dos limiares da história (RIBEIRO, 2020). Ambos nos mostram que as "ondas" ou "potências" inerentes às sublevações populares são capazes de fazer erodir não só as "barragens" e as "falésias", como também as "estátuas" cristalizadas há anos em determinados regimes opressores e distópicos, seja, respectivamente, o período histórico do reinado de Carlos $\mathrm{X}$ e da Restauração dos Bourbon na França, seja o do domínio de Salazar e da implantação do Estado Novo em Portugal. A longa, mas inevitável citação que se segue, da autoria de DidiHuberman, possibilitar-nos-á estabelecer uma relação com o conceito de 'partilha do sensível" (RANCIÈRE 1995), na ótica de Jacques Rancière, a ser vislumbrado nos textos que focalizam a vivência agônica da distopia e o êxtase da realização do desejo utópico, através do eclodir das Revoluções, seja ela a Revolução Francesa ou a Revolução dos Cravos:

Por todos os lados, as pessoas se sublevam: potências. Mais por todos os lados, também, constroem barragens: poderes. $\mathrm{Ou}$, então, protegem-se no topo das falésias, de onde acreditam dominar o mar. As barragens e as falésias parecem ter sido erguidas para conter o movimento de algo que se levanta a partir de baixo e ameaça a ordem das coisas no alto. Assim, os levantes se pareceriam com as ondas do oceano, cada uma delas contribuindo para que um dia, subitamente, a barragem afunde ou a falésia desmorone. Nesse meio-tempo, alguma coisa vai se transformando, mesmo que de modo imperceptível, conforme as ondas vêm. É o "imperceptível" do futuro. É a potência da onda - em todos os sentidos da palavra "potência" -, irresistível mas latente, que passa despercebida até o momento que faz com que tudo exploda. É exatamente isso que os poemas, os romances, os livros de história ou de filosofia, as obras de arte, sabem registrar, amplificando as coisas, dramatizando sob a forma de ficções, utopias, visões, imagens de todos os gêneros. Imagens-sintomas nas quais estaria inscrito, por meio de rastros, de catástrofes morfológicas, que a barragem ou a falésia já não são exatamente as mesmas depois da passagem de uma onda aqui, outra acolá, e assim por diante. Imagensdesejos, tal como Ernst Bloch nomeou tão bem, que surgem ou se levantam com toda a potência para dar forma ao nosso desejo de ultrapassar, de atravessar uma fronteira, saltar a barreira. (DIDI-HUBERMAN, 2019, p. 115-116, grifos do autor). 


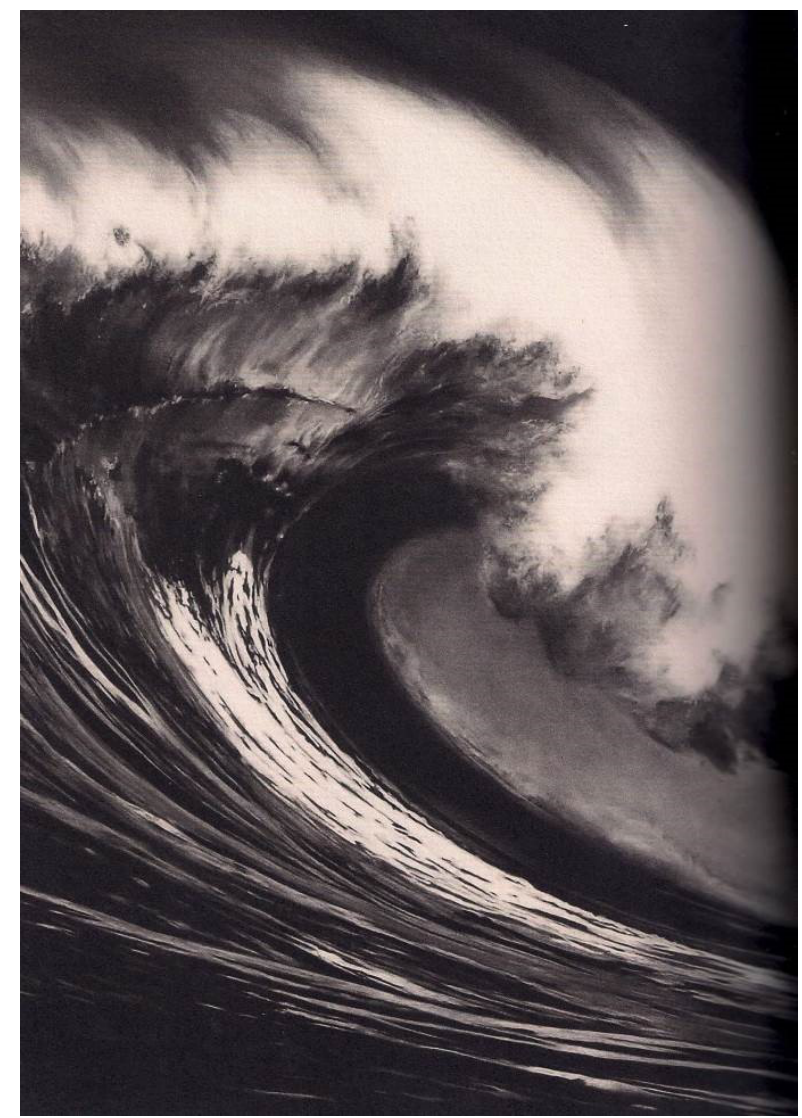

Figura 1 - Robert Longo, Spanish Blood (Lion's Gate), 2005

2 São elas: (Spanish

Blood (Lion's Gate), 2005. Cortesia do artista e da galeria Metro Pictures, Nova York); Untitled (Hellion), 2011; Untitled (Thunder Road XI), 2009; Untitled (Junior's Wave), 2011 e Untitled (Gotterdammerung YO JIMBO), 2005.

Tais imagens estão contidas no artigo

"Ondas, torrentes e

barricadas", de Georges

Didi-Huberman,

publicado na Revista

Serrote, número 33 ,

novembro de $2019, \mathrm{p}$.

$114,120,121,126$ e 127 .
Levando-se em consideração que todas as insurreições sociais possuem "Imagens-sintomas" e "Imagens-desejos", resultantes de tempos disfóricos, marcados por "ondas de protesto" ou "ondas de revoltas", não é gratuito o fato de o artigo do filósofo francês vir a ser ilustrado por fascinantes e instigantes imagens de "ondas enormes" que, ao "revolver o fundo", "agitam toda a atmosfera" (DIDI-HUBERMAN, 2019, p. 116). Tais imagens de assustadoras ondas revoltas de autoria de Robert Longo ${ }^{2}$ tornam-se passíveis de induzir o ultrapassar dos limites entre terra, mar e céu e de marcar um momento de suspeição, suspensão, insubmissão e epifania. “Não é por acaso, afinal, que $O$ Encouraçado Potenkin, de Eisenstein, filme sobre o levante por excelência, tenha início com a imagem de um mar agitado por ondas que vão, com toda a força, fazer afundar uma barragem." (DIDI-HUBERMAN, 2019, p. 116). Também não será por acaso que, no início de Paisagem com mulher e mar ao fundo, de Teolinda Gersão, deparamo-nos com a personagem 
${ }^{3}$ A esse respeito, ver FRYE, Anatomia da crítica. São Paulo: Cultrix. 1973.
Hortense e "sua vida parada à beira-mar" (GERSÃO, 2019, p. 50). Imersa na dor e no desejo iminente de suicídio, após a morte do filho na guerra colonial e a do marido, arquiteto e professor universitário perseguido pelo regime salazarista, a personagem desamparada percebe que "o ar e o tempo tinham deixado de existir", a partir do momento em que "o ruído do mar [que] entrara pela noite invisivelmente diluirá as coisas" (GERSÃO, 2019, p. 10). Nota-se, aqui, que o sem sentido da existência e o luto vivido pela personagem feminina permitem a sua singular percepção referente ao "ruído do mar" - índice metafórico, na narrativa, não só da onipresença do "Senhor do Mar", como também de um "levante" político a nos ser relatado, mais adiante, marcado pelo fluxo e refluxo das ondas. Assim, "uma onda se ergue, levanta-se e volta a cair dispersandose em espuma, mas subitamente volta a se formar com toda a força, desaparece num canto para voltar a aparecer em outro" (DIDI-HUBERMAN, 2019, p. 131). "Imagens-sintomas" já prefigurariam, assim, a "imagem-desejo" - a utopia da transformação social em seu processo de gestação.

É importante ressaltar que, no romance em questão, o mar revestir-se-á de ambiguidade. A princípio, o sentido demoníaco na acepção de Frye 3 : o corpo do filho, "fantasmado e de ausência" (GERSÃO, 2019, p.58), morto no além-mar, será imaginariamente "trazido pelas ondas" ao encontro dos braços da mãe e, uma vez aprisionado por ela em urgência de afeto, será arrastado "para o fundo do mar, sob um manto de folhas" (GERSÃO, 2019, p. 4). Tal imagem representa o fado português, inerente à época da guerra colonial africana: a morte dos "meninos da sua mãe" (PESSOA, 1983, p. 80) - aqueles que iriam ser vítimas das "malhas que o Império tece" (PESSOA, 1983 , p. 80) - morte anunciada desde o momento da partida no "cais de desastre e de amargura, desespero e falsa esperança" (GERSÃO, 2019, p. 62). E, como todo símbolo é ambivalente, mais adiante, no espaço textual, o "mar" demoníaco e "salgado" pelas "lágrimas de Portugal" (PESSOA, 1983, p. 16) revestir-se-á de um sentido apocalíptico, ao erodir a falésia e desencadear a queda do andor de o "Senhor do Mar". Constatação inevitável: "Enquanto a distopia constrói a figura da sociedade malévola, perversa e infeliz, a utopia constrói a figura de uma sociedade justa, abundante, livre e feliz" (CHAUÍ, 2019, p. 56, grifo do 
autor). Marilena Chauí, ao refletir sobre a presença da distopia nos regimes políticos, afirma que

A distopia impõe uma inversão de sinais nos principais elementos da utopia, assim, o caráter normativo do discurso utópico é identificado com todas as formas de repressão física, psíquica, ética, política e cultural; a vontade de transparência é identificada ao olhar onividente do poder vigilante enquanto a sociedade e o Estado são inteiramente opacos e invisíveis para os indivíduos; a legalidade é exercício puro da força e da violência; o cotidiano é monótono, inexpressivo, desprovido de sentido. A ciência e a técnica, longe de serem liberadoras, organizam-se para produzir o panóptico absoluto ou a sociedade de vigilância e da disciplina totais, agindo sobre as condições biológicas e psíquicas dos seres humanos para aviltá-los no mais profundo do seu ser e impedir todo e qualquer protesto. Brutal, o mundo novo é o coletivismo anônimo e nivelador, destruidor da liberdade e da dignidade humanas. Presente e futuro são idênticos, pois o tempo está imobilizado. (CHAUÍ, 2019, p. 56).

Em Paisagem com mulher e mar ao fundo, as "mãos" punitivas e vigilantes da professora Áurea, representação metonímica da ideologia do Estado Novo, reduplicam as de António de Oliveira Salazar, e a educação imposta às alunas busca impedilas de pensar e de sentir livremente; no entanto, as "mãos" adolescentes e rebeldes de Hortense subvertem o castigo. Ao escrever e/ou inscrever no quadro negro da escola palavras de resistência, revolta, sublevação e denúncia, a personagem transgressora rasura o poder instituído e comprova que "as palavras podiam ter mais força do que as armas" (GERSÃO, 2019, p. 100). Hortense, ao grafar com giz "adeus" em lugar de "Deus", ironiza o impositivo exercício de redação, típico de um círculo "panóptico absoluto que enfatiza a sociedade de vigilância, disciplina e controle totais" (CHAUÍ, 2019, p. 57). Hortense é punida, pois caberia a ela somente escrever o único tema de devoção ao regime salazarista: "Redacção a pátria, redacção a família, redacção Deus” (CHAUí, 2019, p. 119). Uma vez adulta, ao partir para a descoberta do prazer e do corpo, a personagem constata que "é da força do amor que nasce o mundo" (GERSÃO, 2019, p. 35). Em decorrência disso, a transgressão e a insurreição acentuam-se: Hortense desobedece a seu pai, sai de casa e desce a escada, o que leva o poder paterno e especular do sistema a constatar que "a ordem que 
4 "Homem novo" aquele que, possuidor de uma consciência de classe, irá consolidar o ideal revolucionário. Tal expressão, provavelmente, relaciona-se aos ideais do Socialismo utópico. fora a dele estava quebrada, desfeita, o seu império em ruínas, como uma casa construída sobre a areia" (GERSÃO, 2019, p. 38, grifos nossos). Hortense levanta-se como uma onda no mar e derruba arestas onde o mundo principia.

Em Paisagem com mulher e mar ao fundo, há o olhar de um sujeito testemunha da História - uma mulher - corpo que transitou do desamparo absoluto para a inauguração de uma nova paisagem, ao deslocar o "mar" (demoníaco) do seu centro e colocá-lo ao "fundo". Nesse romance de Teolinda Gersão, vislumbra-se não só o corpo coletivo em festa ("o coração da cidade pulsando, um só corpo solidário" - GERSÃO, 2019, p. 98), como também o corpo individual de uma criança que acaba de nascer - esperança de um novo tempo ou de uma nova ordem social e utópica, momentaneamente vitoriosa. No imaginário da personagem, "uma criança chegando do incerto, da bruma, e tendo de repente um corpo e um rosto. Esse, e não outro" (GERSÃO, 2019, p. 190). Eis o momento do nascimento dessa criança, filho de Clara e de Pedro, o filho da Hortense que morreu em África, "rosto ausente" que partiu de forma prematura a ser substituído por outro ("imagem-sintoma" ou "imagem-desejo": o "homem novo"?)": "um pequeno corpo húmido, perfeito, sufocado, abrindo uma passagem, puxado por outras mãos através de uma passagem, experimentando bruscamente o ar e o espaço, o choque da sombra contra a luz" (GERSÃO, 2019, p. 98, grifos nossos).

No cerne da distopia, encontra-se um "regime político tirânico, aonde os cidadãos obedecem às leis por medo de castigos e são tomados como escravos" (CHAUÍ, 2019, p. 8); em contraposição, o mundo da sublevação, da criação e da arte em liberdade tende a instaurar a utopia. Em Paisagem com mulher e mar ao fundo, as "mãos" - elemento metonímico, representante do metafórico social - ora possuem um sentido apocalíptico e dionisíaco, ora demoníaco e cerceador do prazer e da liberdade. Relacionadas com a práxis social, tornam-se reflexo do desejo utópico, revestindo-se de uma singular importância. Passíveis de reverter o sentido do mundo distópico, as mãos dos arquitetos, que desenham e constroem cidades imaginadas e que buscam privilegiar a "harmonia possível - o espaço do indivíduo e o espaço da comunidade, o espaço do repouso, do tempo livre, do prazer, do trabalho, do amor e da festa, o lugar do encontro e o lugar da passagem" (GERSÃO, 2019, p. 104), 
serão aprisionadas, metaforicamente mutiladas e realmente torturadas. No cenário político e distópico, marcado pela submissão, "resignação" e pela "obediência" (GERSÃO, 2019, p. 87), a "mão de O.S. levantava-se acima de todas as coisas, fazendo parar o país, parar o tempo, retroceder séculos" (GERSÃO, 2019, p. 6, grifo nosso). Durante décadas, "a sua mão parava o vento da mudança e espalhava a areia negra do medo, apertava em torno das casas a mordaça do silêncio, a sua mão castradora retirava ao povo a força da revolta" (GERSÃO, 2019, p. 87, grifos nossos). O "Senhor do Mar", onipotente e onipresente, desejará sempre calar os desejos ou "ondas de emancipação", os atos de subversão e as palavras que entoam a liberdade. No entanto, esse santo padroeiro da aldeia à beira-mar não conseguirá impedir "o levante", esse "fenômeno originário de um determinado tipo de situação concernente à vida histórica da sociedade humana" (DIDI-HUBERMAN, 2019, p. 7). Tal "fenômeno de potência" ou "onda de energia social" permitirá a "dispersão das coisas estabelecidas, força resultante da ressaca fluida capaz de destruir as barragens e falésias - isto é, instituições aparentemente tão sólidas." (DIDI-HUBERMAN, 2019, p. 117). Por isso, a festa de devoção ao Senhor do Mar se transformará em festa de transgressão e de sublevação; a vivência de um tempo disfórico deflagrará a necessidade de se "voltar as costas ao mar" para "ir ao encontro da terra" em processo de transformação, de comunhão e de partilha. Assim desejava o arquiteto Horácio: "As suas mãos próximas das mãos dos camponeses encontravam-se na terra umas e outras" (GERSÃO, 2019, p. 103, grifos nossos). No mundo da criação e da arte em liberdade, tecido em sonhos e em planos ou projetos, recusados pelo sistema opressor, Horácio, "o inventor do mundo", desejava "distribuir, redistribuir por todos o sol e o espaço" (GERSÃO, 2019, p. 103). Logo, o processo de "levante" popular, "ação conjunta e solidária" que deveria nascer para "sufocar o espaço asfixiado e egoísta de O.S." (GERSÃO, 2019, p. 104), será representado por uma "imagemsintoma" ou "imagem-desejo" ligada à terra: "Uma comunidade subterraneamente germinando e de repente levantando-se, uma seara, um exército, em linha de batalha" (GERSÃO, 2019, p. 105, grifos nossos). Tal "seara", aqui representada por uma metáfora terrestre, torna-se análoga à "onda" marítima didihubermaniana que, após crescer subterraneamente, em clave de 
${ }^{5}$ Assim Didi-

Huberman (2019, p.

117), sutil e perspicaz

estudioso das imagens

contemporâneas,

"por meio da imagem

de uma onda de

paralelepípedos

quebrando sobre

a areia da praia e

agitando [... to toda a

atmosfera até o alto

do céu", elucida o

"slogan de maio de

68": "debaixo dos

paralelepípedos, a praia!". potência e resistência, atinge com toda a sua força a superfície, afundando a "barragem" que se julgava sólida e irremovível - a Instituição do poder constituído. ${ }^{5}$ Tal sublevação ou práxis do levante faz com que O.S. caia do andor do alto da falésia e se transubstancie em estátua-corpo que se desmorona. Claro está que "a mobilidade utópica provém de sua energia como projeto e práxis, como trabalho do pensamento, da imaginação e da vontade de destruir o intolerável" (CHAUÍ, 2019, p. 61). E o romance de Teolinda Gersão, assinalado pelo fluxo e refluxo das ondas típicas de um "levante" ou insurreição, confirma a práxis social:
É de uma situação de opressão, paralisada e vazia - a maré vaza de um povo - que se parte para a transformação. Assim, veremos "um povo de afogados", "perdido pela noite", "embarcado, sem força nem vontade, no barco da loucura", transformar a terra da opressão na terra dos homens em festa". Em Paisagem com mulher e mar ao fundo, a memória subjetiva, assentada na efetividade dos acontecimentos, propicia a intervenção na pólis. Só isso bastaria para ficarmos, para sempre, seduzidos pelo romance. (FARIA, 2019, orelha de Paisagem com mulher e mar ao fundo, de Teolinda Gersão).

Tal poética narrativa, inserida na contemporaneidade do século XXI, põe em cena a ressonância de ecos intertextuais e a presença antropofágica de imagens sobreviventes e espectrais retidas no inconsciente coletivo e/ou no imaginário político e cultural. Ao propor deslizamentos e deslocamentos de sentidos, o romance de Teolinda Gersão cria novas significações passíveis de refletir o circuito dos afetos que produzem corpos políticos, individuais e coletivos. Assinaladas pela subversão, transgressão e denúncia em relação às formas do poder, as criações literárias e artísticas instauram novas corporeidades e formas de ser.

Na ficção portuguesa contemporânea, há vários exemplos de corporeidade social produzida por um círculo de afetos baseado no desamparo (SAFATLE, 2018). Várias são as personagens que, uma vez despossuídas de seus atributos e predicados individuais, se assumem como sujeitos políticos ou corpos dotados de vontade consciente em defesa de um bem comum; corpos que rompem com a norma instituída e que corroem as estratégias do poder. Ao retomar os conceitos de Psicanálise freudianos, Safatle afirma que "toda ação 
política é inicialmente uma ação de desabamento e só pessoas desamparadas são capazes de agir politicamente" (SAFATLE, 2019, p. 50). Inerentes à internalização do desamparo, encontram-se "a dor que não cessa" e o acúmulo de necessidades que não obtém satisfação." (FREUD apud SAFATLE, 2018, p. 53). Em Paisagem com mulher e mar ao fundo, observam-se duas situações paradigmáticas desta situação: a primeira diz respeito ao desamparo sentido pela Hortense, que terminou impulsionando a sua emancipação pessoal, a sua relação com o Horácio e a conquista de "um espaço livre, invulnerável, para onde pudesse voltar sempre, uma casa segura contra o tempo e o vento, lentamente construída e lentamente amada" (GERSÃO, 2019, p. 93). A segunda situação de desamparo absoluto, que impulsionará o "povo [errante] de afogados [a] voltar à superfície" (GERSÃO, 2019, p. 163), será marcada pela "revolta acumulada" que levará ao destronamento do "Senhor do Mar". O momento da peregrinação de um povo que ia "avançando mecanicamente, um povo como uma chaga, atravessando um deserto queimado pelo sol e devorado pela sede" (GERSÃO, 2019, p. 142) irá deflagrar a imagem marítima dionisíaca e apocalíptica que provocará a derrubada do sistema político e opressor que se julgava inabalável: "a rua é um mar de gente que se aperta, uma multidão abrindo alas dos dois lados" (GERSÃO, 2019, p. 149. grifos nossos); "sobre os curvados, o Senhor avança, como se caminhasse sobre um mar de povo, mas de repente, no extremo da falésia, a imagem cai" (GERSÃO, 2019, p. 152, grifos nossos). Tal "levante", construído lenta e subterraneamente pelo desamparo, opera a transformação do mundo e instaura a utopia: a volta dos emigrantes desterrados e dos perseguidos políticos expatriados na geografia do exílio. Vejamos como o fato referido vem a ser enfatizado pelas morfologias textuais, assinaladas pelo emprego de ações verbais no gerúndio: “Um povo perdido pelo mundo reunindo os pedaços dispersos do seu corpo e voltando. Pisando outra vez a terra abandonada e agora sua, finalmente sua, se a luta das suas mãos não afrouxar." (GERSÃO, 2019, p. 171-172, grifos nossos). Assim, "um rosto deslumbrado e suspenso que desaparecia num país estranho e ninguém encontrava nunca mais" (GERSÃO, 2019 , p. 160) poderia vir a sair da invisibilidade da sombra e ganhar a luz, pondo fim ao sofrimento até então imposto pela autoridade, hierarquia e poder. Na utopia do retorno, 
${ }^{6}$ Remetemos, entre outros, à leitura de $O$ Dinossauro Excelentíssimo, de José Cardoso Pires e a $O$ ano da morte de Ricardo Reis, de José Saramago. evidencia-se a alusão intertextual e a imagem sobrevivente ou remanescente relacionada, analogamente, com a esperança da anistia brasileira: "porque eu vou voltar. Uma canção do Brasil." (SABIÁ, 1969). No entanto, nas dobras estilhaçadas da memória, há imagens labirínticas, fantasmáticas ou espectrais que assombram os homens e, entre tantas outras ditatoriais e fascistas, surge a de António de Oliveira Salazar que jamais desaparecerá da cena literária ou histórica. ${ }^{6} \mathrm{E}$ a voz de Hortense, em Paisagem com mulher e mar ao fundo, registra isso, mesmo após os sujeitos terem vivenciado a momentânea "terra dos homens em festa": "Ninguém vai nunca derrubar O.S. Ficará no seu trono pela eternidade adiante. Um dia dirão que nunca existiu e ressuscitá-lo-ão noutro lugar com outro nome" (GERSÃO, 2019, p. 189).

Aby Warburg, em Histórias de fantasmas para gente grande, considera "imagens" tanto os objetos materiais quanto as formas de pensamento, ou seja, os modos de conceber, de pensar, de assimilar, de formular, em suma, um modo de pensar através de imagens. Ao discorrer sobre as forças atuantes na composição das imagens, o historiador da arte e teórico cultural alemão mostra que "essas vêm do passado e prosseguem, na superfície ou no subsolo, consciente ou inconscientemente, para além da sua cristalização" (WARBURG, 2015, p. 19). Logo, um objeto (uma tela, uma gravura, uma fotografia, uma escultura) retido na memória permanece irradiando um sentido que pode vir a ser recuperado e metamorfoseado, dando origem à noção de "engrama" - "forma da memória cultural e coletiva", capaz de enlaçar o domínio da interioridade com o do exterior e de "articular o dionisíaco com o apolíneo" (WARBURG, 2015, p. 12). E, pelo fato de "se enraizar em experiências e comoções muito intensas, que penetram na subjetividade e permanecem armazenadas, podem vir a afluir posteriormente" (WARBURG, 2015, p. 11). Nisso, residem as potências fantasmáticas das imagens - "espaços de devoção" que se tornam "espaços de reflexão", a partir do momento em que o homem se distancia criticamente das imagens originais. E, como a revivescência do páthos diz respeito tanto às paixões felizes quanto às tristes, torna-se interessante observar o seguinte processo dialético: a imagem da decomposição do Império (Salazar morto ou Marcelo Caetano deposto) é, ao mesmo tempo, a imagem da cristalização, ou seja, a imagem-sobrevivente 
${ }^{7}$ A esse respeito, ver DIDI-HUBERMAN, Georges. A imagemsobrevivente: história da arte e tempo dos fantasmas segundo Aby Warburg. Trad. Vera Ribeiro. Rio de Janeiro: Contraponto, 2013.

\footnotetext{
${ }^{8}$ Comparemos a mesma imagem antes e depois do "levante" ou insurreição popular: “O Senhor do Mar está limpo, sem pó, com o fato de cetim vermelho engomado de fresco, caindo em pregas fundas" (GERSÃO, 2019, p. 47) e "está caído no chão, com as roupas desfeitas, inerte, de madeira pintada, o cabelo em pó, o manto de cetim rasgado." (GERSÃO, p. 153).
}

que poderá ressurgir a qualquer momento e que suscita o seguinte questionamento: "Algum dia podemos prever o que, do passado, é chamado a sobreviver e a nos assombrar no futuro?" (DIDI-HUBERMAN, 2013, p. 428).

Em Paisagem com mulher e mar ao fundo, observa-se exatamente isso: a "imagem-sintoma" (assinalada por "fósseis em movimento e montagem da memória" ${ }^{7}$ reflete-se na figura icônica do "Senhor do Mar", análoga alegoricamente à de "O.S." Uma vez integrada à narrativa, tal imagem será reduplicada na capa e na contracapa do livro que possui ilustração design de Susana Cruz, o que nos possibilita estabelecer o diálogo interartes - texto literário e gravura. O olhar do leitor irá captar, na capa, em primeiro plano, o corpo fantasmático de Salazar: o perfil do seu rosto branco debruado de vermelho com cabelos pretos e o seu corpo, em formato do mapa de Portugal em vermelho-sangue, remetem não só à imagem do "Senhor do Mar", descrita no romance ${ }^{8}$ como também aludem à violência, à barbárie e ao sangue derramado no período totalitário. $\mathrm{O}$ formato do mapa parece assemelhar-se, por sua vez, a um hábito religioso que, ao revestir a figura do ditador, poderá vir a representar a crença imposta ou a aliança da Igreja com o Estado Novo. Encostado a ele, e de costas para o leitor, em sua menor dimensão, o corpo de uma mulher com um vestido negro (luto) e a cabeça baixa (desolação, desamparo, tristeza) (Hortense?, Clara?, Uma mulher anônima, representante de "quantas mães [que] choraram" [e de] "quantas noivas [que] ficaram por casar para que fosses nosso, ó mar?"(PESSOA, 1983, p.16). Em segundo plano, um cemitério: inúmeras e diminutas lápides negras ou pedras tumulares enfileiradas possuem, em seu centro, cruzes brancas. Na contracapa, vêse apenas uma única lápide em tamanho maior enraizada na terra representada por um único traço negro e retilíneo. Logo, ao final da obra, a figura simbólica e até então onipresente do ditador desaparece e é substituída pela pedra tumular que reina soberana (morte de Salazar?). O tema da morte e da opressão, predominante no espaço textual remete-nos à história trágico-marítima (ou será trágico-política?) de sujeitos à beira-mar sitiados por instituições, agentes e monumentos do fascismo, aqui emblematizado, como vimos, pela sigla "O.S." (Oliveira Salazar) e pelo "Senhor do Mar". Por fim, o que se vislumbra, na capa de Paisagem com mulher e mar ao fundo e 
no próprio romance, "não são os fantasmas da história - mas seus fantasmas irrefutáveis, que sempre podem voltar para assombrar a nossa consciência histórica." (DIDI-HUBERMAN, 2019, p.130). Contra eles, restam-nos a "barricada", "um tipo de barragem improvisado às pressas com o objetivo de se defender, de deter o avanço da polícia ou do exército"; "também onda, uma força em movimento" (DIDI-HUBERMAN, 2019, p. 131), a onda espectral de um levante.

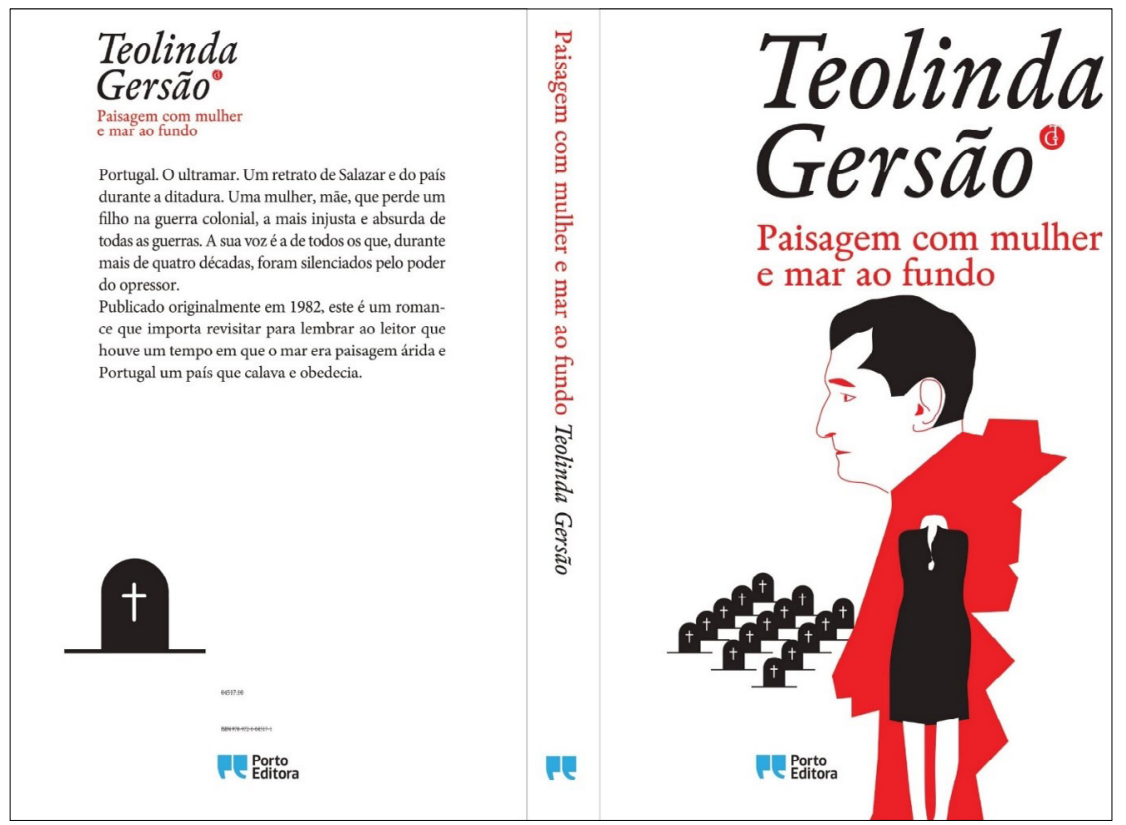

Figura 2 - Capa e contracapa de Paisagem com mulher e mar ao fundo, de Teolinda Gersão. Nova edição revista pela autora. Porto Editora, 2019. Design e ilustração da capa: Susana Cruz.

No romance em questão, o leitor depara-se com personagens masculinas e femininas inseridas nas décadas de 60 e 70 do século XX, detentoras de "corpos arruinados pela História-documento e corpos transformados pela linguagemacontecimento", como tão bem afirmou Jorge Fernandes da Silveira, ao estudar a Poesia 61 (SILVEIRA, 1986). Em Paisagem com mulher e mar ao fundo, lemos: "era a festa da morte, gritam, mas doravante é a festa da vida, ele caiu do seu trono e somos nós agora os senhores do mar e os senhores da terra, desvendámos o enigma e encontramos a saída do reino, não partiremos mais porque a terra é nossa" (GERSÃO, 2019, p. 152). Eis, portanto, o poder dos "levantados do chão": as vozes e as 
mãos de um povo antes "afogado" e desamparado revertem a situação de submissão e não permitem a perversão dos valores humanitários.

No entanto, o processo dialético da História nos leva a reconhecer que a utopia revolucionária, presente na Revolução dos Cravos em Portugal, "não instituiu a liberdade, a igualdade, a justiça e a felicidade" (CHAUÍ, 2019, p. 49) como se esperava. Passado um período de euforia, as estruturas políticas e sociais revelaram-se precárias e problemáticas, envolvidas em disputas internas, instaurando a imagem de uma sociedade em concordância e consonância consigo mesma, sem diminuir as desigualdades sociais e incapaz de acatar a heterogeneidade social e a pluralidade dos modos de vida esperados em uma democracia. Constata-se, assim, que "a distopia descreve um mundo intolerável, mas, ao transformá-lo em fantasma, reduz o intolerável à dimensão da ilusão. Torna-se ontologia do ilusório e, portanto, se transforma em ideologia, perde o poder crítico, ruma para o fatalismo e cai no desalento do fim da história." (CHAUÍ, 2019, p. 61). Tal constatação, inerente a fatos históricos que ultrapassam uma temporalidade demarcada, provoca o seguinte questionamento de Marilena Chauí: como realizar, de forma efetiva, "o projeto utópico da "expansão do nosso ser e da plena fruição do nosso desejo? (CHAUÍ, 2019, p. 61). Em busca de uma resposta, ocorre-nos apenas "o salto no escuro". Em Paisagem com mulher e mar ao fundo, vemos o entrecruzar das vozes das personagens femininas entre aspas, o que pode denotar um sussurro, uma confidência, um rumor de algo que ainda virá e que se encontra em suspensão: "(Procuro um rosto ausente. Um homem que partiu, que se ausentou. Não digas nada, que sabes tu das coisas. Da ausência, da morte, eu sei. Do amor eu sei, é um salto no escuro um salto mortal no escuro)" (GERSÃO, 2019, p. 188, parênteses da autora, grifos nossos).

Vladimir Safatle, no capítulo "Política Inc.", inserido em O Circuito dos Afetos: Corpos politicos, desamparo e o fim do indivíduo, ao comentar que "saltar no vazio talvez seja atualmente o único gesto realmente necessário" (SAFATLE, 2018, p. 35), reproduz uma foto de Yves Klein - Leap into the Void (Salto no Vazio), datada de 1960, em que um homem parece saltar do telhado de uma casa, rente ao muro, para uma quase deserta rua de subúrbio de alguma cidade indeterminada. O seu corpo, vestido com terno e gravata, projeta-se no ar, e esse momento 
de suspensão e suspeição, congelado pela câmera fotográfica, torna-se impactante. Penso que podemos considerar essa foto uma "imagem-páthos" (assinalada por "linhas de fratura e fórmulas de intensidade"), na acepção de Didi-Huberman (2013). Não vemos o corpo cair ou estatelar-se, mas pressupõese a queda iminente e imagina-se a situação-limite que levou o sujeito a dar o salto. Diz Safatle: "Saltar no vazio com a certeza irônica de quem sabia que um dia essa hora chegaria em sua necessidade bruta, que agora não há outra coisa a fazer". E acrescenta: "Pois, como dizia Yves Klein, 'no coração do vazio, assim como no coração do homem, há fogos que queimam' (SAFATLE, 2018, p. 35). Mesmo consciente da impotência do seu ato - permanecer no ar não será possível -, o gesto não paralisa o sujeito, antes, move-o. Logo, "saltar no vazio não será inerte", pois "o impossível é o lugar para onde não cansamos de andar, mais de uma vez, quando queremos mudar de situação. Tudo o que amamos foi um dia impossível." (SAFATLE, 2018, p. 35). Tais reflexões possibilitam ao pesquisador chileno e professor titular do Departamento de Filosofia da USP tecer, inclusive, a seguinte conjectura a respeito da arte: "A arte tentou durante décadas forçar o limite do possível de várias formas, mas deveria ter tentado saltar mais no vazio." (SAFATLE, 2018, p.35). E nós nos perguntamos, após a releitura e a tentativa de decifração de Paisagem com mulher e mar ao fundo: "Saltar no vazio" será o mesmo que "Saltar no escuro"?

Em Paisagem com mulher e mar ao fundo, não veremos apenas "o erotismo do corpo e o prazer da linguagem contra a frieza das coisas mortas" (SILVEIRA, 1986, p. 233), como nos ensina Jorge Fernandes da Silveira, em Maio de Poesia 61, mas também a presença de "corpos fantasmados ou corpos de ausência" (GERSÃO, 2019, p. 58) que provocam o despertar da consciência de classe, passível de transformar a realidade social e a relação de cada indivíduo consigo mesmo, com o outro que está ao seu lado e com a sua nação. Imerso no desamparo e na melancolia, o corpo de Hortense, antes capaz de reivindicar visibilidade e liberdade, tinha-se metamorfoseado, após a perda de Pedro e de Horácio, e, agora, "ela era uma sombra num vidro, uma sombra passando, atravessando as coisas sem tocá-las, um corpo de vidro caindo de uma janela alta, rebentando em estilhaços de granada, para viver seria preciso recuperarse, reunir os pedaços dispersos (GERSÃO, 2019, p. 29, grifos 
nossos). E isso ela somente conseguirá algum tempo depois, ao reintegrar-se a si própria e ser impulsionada, solidariamente, em direção ao outro.

Safatle, na obra referida, ao refletir sobre a articulação entre afetos e corpo social, afirma que "Uma sociedade que desaba são também sentimentos que desaparecem e afetos inauditos que nascem. Por isso, quando uma sociedade desaba leva consigo os sujeitos que ela mesma criou para reproduzir sentimentos e sofrimentos" (GERSÃO, 2018, p. 16). No entanto, como "sujeitos que compõem o corpo político criam e sustentam vínculos" (SAFATLE, 2018, p. 20), "uma nova corporeidade social pode ser produzida por um circuito de afetos baseado no desamparo" (SAFATLE, 2018, p 21). Tal dinâmica de circulação de afetos, responsáveis por operar transformações, leva a personagem Hortense a "lutar contra o mar" e a "partir o mar como se fosse um espelho" (GERSÃO, 2019, p. 77), a reinventar "palavras verdadeiras" (opostas ao "poder opressor das palavras falsas e das frases feitas") (GERSÃO, 2019, p. 128), a "lembrar-se de Clara como um exercício de sobrevivência" (GERSÃO, 2019, p. 41), a reinventar o amor para salvar a nora grávida que tenta o suicídio - ambas corpos desabrigados a querer "saltar no vazio". Hortense possibilitará o nascimento do neto - paradigma talvez do "homem novo" que, movido pela utopia da resistência, será capaz de subverter a distopia da submissão, assumindo-se agente de uma transformação social. A ruína do corpo inerte de Clara impulsiona o desejo de Hortense de estar viva e ser corpo ativo e solidário na História. Logo, a pulsão de morte (Thánatos) e a pulsão de vida (Eros) são forças essenciais, antagônicas e suplementares, semelhantes, respectivamente, às duas faces da distopia - submissão e resistência.

Paisagem com mulher e mar ao fundo, de Teolinda Gersão, nos dá uma exata lição de vida, a partir da relação entre o luto e a revolta, a perda e o levante, o desejo e a memória: "não é nunca sozinho que se parte para criar seja o que for, é sempre com os outros" (GERSÃO, 2019, p. 100). A perversão dos valores humanitários, o primado do individualismo, o domínio e a execração dos que se opõem ao regime estabelecido e a censura à liberdade de expressão, inerentes à distopia da submissão, deveriam ser substituídos pela união, solidariedade, exercício da liberdade, em síntese, pela utopia da resistência, assinalada 
pelo "gesto livre do amor, do desejo e do sonho" (GERSÃO, 2019, p. 106). Cabe a nós "pensar sempre no ritmo que vai dar lugar aos fluxos e refluxos das ondas da história" (DIDIHUBERMAN, 2019, p. 124). Cabe a nós, imersos no tempo de redefinição e reavaliação de posturas políticas, observar os impasses da história. Claro está que convém lutar contra o esquecimento e ficar atentos, pois os "fantasmas irrefutáveis," insistimos, sempre podem voltar para assombrar nossa consciência histórica e impedir ou deflagrar os "levantes" insurrecionais.

\section{REFERÊNCIAS}

ANDRESEN, Sophia de Mello Breyner. O nome das coisas. Lisboa: Moraes, 1977.

CHAUÍ, Marilena. Utopia, revolução, distopia e democracia. In: NOVAES, Adauto (org.). Mutações: a outra margem da política. São Paulo: Edições SESC São Paulo, 2019.

DIDI-HUBERMAN, Georges. A imagem sobrevivente: história da arte e tempo dos fantasmas segundo Aby Warburg. Tradução Vera Ribeiro. Rio de Janeiro: Contraponto, 2013. (Coleção ArteFíssil, 5).

Ondas, torrentes e barricadas. Serrote: Uma revista de ensaios, artes, visuais, ideias e literatura. Rio de Janeiro,n.33, p. 114-143, nov. 2019.

FARIA, Ângela Beatriz de Carvalho. Corpos e afetos (metamorfoseados e transgressores) na arte e na narrativa do século. Texto apresentado no XXI Congresso da ABRAPLIP. Belém do Pará: UFPA, 2019. [inédito].

GERSÃO, Teolinda. Paisagem com mulher e mar ao fundo. Nova edição revista pela autora. Porto: Porto Editora, 2019.

MAGALHÃES, Isabel Allegro. O tempo das mulheres: a dimensão temporal na escrita feminina contemporânea. Ficção portuguesa. Lisboa: Imprensa Nacional: Casa da Moeda, 1987. 
PESSOA, Fernando. Obra poética. Volume único. Seleção, organização e notas de Maria Aliete Galhoz. Cronologia por João Gaspar Simões. Introdução por Nelly Novaes Coelho. Rio de Janeiro: Editora Nova Aguillar S.A., 1983.

RANCIÈRE, Jacques. A partilha do sensível: Estética e política. 2a. ed. Tradução de Mônica Costa Netto. São Paulo: EXO; Editora 34, 2009.

SABIÁ. Intérprete: Chico Buarque de Hollanda. Compositor: Chico Buarque de Hollanda e Tom Jobim. In: CHICO Buarque Não vai Passar, vol. 4. Intérprete: Chico Buarque. [S. 1.]: Mariola Edições Musicais, 1968. 1 CD. Informações retiradas do site do compositor: http://www.chicobuarque.com.br/construcao/ mestre.asp?pg=sabia_68.htm

SAFATLE, Vladimir. O circuito dos afetos: corpos políticos, desamparo e o fim do indivíduo. Belo Horizonte: Autêntica Editora, 2018.

SILVEIRA, Jorge Fernandes de. Portugal Maio de Poesia 61. Portugal: Imprensa Nacional; Casa da Moeda, 1986.

SOUZA, Ricardo Timm et al. (org.). Walter Benjamin: barbárie e memória ética. Porto Alegre: Zouk, 2020.

WARBURG, Aby. Histórias de fantasmas para gente grande Aby Warburg: Escritos, esboços e conferências. Organização: Leopoldo Waizbort. Tradução Lenin Bicudo Bárbara. São Paulo: Companhia das Letras, 2015. 


\section{ABSTRACT \\ Paisagem com Mulher e Mar ao Fundo: How to Forget the Flow and Backflow of Waves?}

Assuming that "history and art teach that revolt is usually born from mourning and spreads in a whirlwind that mixes personal and collective laments, the next and the distant, in an extraordinary collective emotion," Georges Didi-Huberman, philosopher and art historian, in the article "Waves, torrents and barricades," published in the Serrote Magazine edited by the Moreira Salles Institute, shows us how political uprisings or insurrections ("powers" or "waves"), in a gradual and imperceptible way, become capable of eroding a constituted power that was thought to be immovable ("dams" or "cliffs"). And this is exactly what we will find iin Paisagem com mulher e mar ao fundo, a novel by Teolinda Gersão, one of the most renowned contemporary Portuguese writers, re-edited in 2019: the presence of a popular uprising, in a village by the sea, besieged by institutions and images of fascism, at the time of António de Oliveira Salazar's government. The novel in question, by metaphorically discussing the April 1974 Revolution, problematizes the concepts of dystopia and utopia, sets in motion "the circuit of affections, political bodies and helplessness," which, in the view of Vladimir Safatle, promotes "the end of the individual," circumscribing him as an agent of social transformation.

Keywords: Paisagem com mulher e mar ao fundo, Teolinda Gersão, Utopya, Dystopia. 
Ângela Beatriz de Carvalho Faria é Doutora em Letras (Literatura Portuguesa) pela Universidade Federal do Rio de Janeiro. Atua nos Cursos de Graduação, Especialização em Literaturas Portuguesa e Africanas, Mestrado e Doutorado. Desenvolve pesquisa e orienta na área de Literatura Portuguesa. Coordena o Projeto de Pesquisa "A (im)possibilidade de dar corpo ao passado na arte e na narrativa dos séculos XX e XXI", no Programa de Pósgraduação em Letras (Letras Vernáculas) da Faculdade de Letras da UFRJ (CAPESPrint-UFRJ). 